\title{
TRANSFORMASI PERTUNJUKAN WAYANG BEBER JAKA KEMBANG KUNING MENJADI PERTUNJUKAN TEATER PANGGUNG
}

\author{
Wahid Nurcahyono \\ Institut Seni Indonesia Yogyakarta
}

\begin{abstract}
Abstrak: Secara visual, Wayang Beber tidak lagi memiliki tampilan yang menarik bagi masyarakat saat ini. Hal tersebut menjadi dasar penelitian ini yang bertujuan untuk menyajikan pertunjukan Wayang Beber yang dapat diterima dan diapresiasi keindahannya oleh masyarakat. Wayang Beber perlu diadaptasi menurut standar hiburan saat ini untuk membuatnya menarik bagi masyarakat sekarang. Adaptasi ini dilakukan dengan cara re-interpretasi isi cerita untuk menyajikan konten yang lebih relevan dan mudah untuk diterima. Dengan menggunakan bentuk pertunjukan Teater Terlibat (Immediate Theatre) yang melibatkan komunikasi secara intim dengan penonton dalam pementasannya, akan dihasilkan sebuah pertunjukan Wayang Beber yang lebih mengakomodasi selera masyarakat saat ini.
\end{abstract}

Kata Kunci: Wayang Beber, tidak menarik, komunikasi intim

\begin{abstract}
Wayang Beber is no longer visually attractive for the society these days. This becomes the reason for this research's aim to present a more appealing Wayang Beber performance which the aesthethics can be appreciated even by current society. In order to do so, Wayang Beber needs to be adapted according to the recent entertainment standard so it may be well-received. This adaptation is done through re-interpretation of the story that leads to telling a more relevant and easier content for the society. Using Immediate Theatre form, in which audience is directly involved in the stageplay to incite an intimate communication, will result in a Wayang Beber performance that is more accomodating to the society.
\end{abstract}

Key Words: Wayang Beber, unattractive, intimate communication

\section{Pendahuluan}

Kesenian Wayang Beber termasuk tergolong tua usianya yaitu berasal dari masa akhir zaman Hindu di Jawa. Pada mulanya Wayang Beber melukiskan ceritacerita Wayang dari epos Mahabharata, tetapi kemudian beralih dengan cerita-cerita Panji yang berasal dari kerajaan Jenggala pada abad ke-XI dan mencapai jayanya pada zaman Majapahit sekitar abad ke-XIV-XV (Haryanto, 1988).

Perombakan total Wayang Beber terjadi pada zaman Kerajaan Demak Bintoro pada abad XV. Waktu itu, pemegang pemerintahan Raden Patah putra ke-13 Raja Majapahit terakhir amat cinta terhadap
Wayang. Sampai-sampai Wayang yang hidup dan berkembang di kerajaan Majapahit diboyong ke Demak. Ada tiga gulungan Wayang yang dibawa dari Majapahit. Satu gulungan berisi cerita Arjuna Wiwaha, Mahabharata dan Arjuna Sasrabahu. Dua lainnya berisi cerita Damarwulan dan Panji tetapi kehadiran Wayang ini ditolak oleh para wali. Lukisan Wayang kala itu gambarnya memang mirip seperti manusia biasa, ini dinilai haram menurut Islam.

Maka, berdasar sidang para wali, Wayang tetap dilestarikan tetapi harus diganti rupa. Maka, gambar Wayang pun diubah bentuk maupun gayanya secara 
imajiner disesuaikan dengan watak tokohnya. Sehingga bentuk Wayang memang berbeda jauh, hidung panjang, rambut digelung, prinsipnya mirip Wayang kulit zaman sekarang, hanya saja masih tetap dalam gulungan. Banyak sekali Wayang baru yang diproduk oleh kerajaan Demak antara tahun 1440 - 1486. Tokoh pembuat Wayang yang terkenal di zaman itu adalah Sunan Giri, Sunan Bonang, dan Sunan Kalijaga.

Bahkan, masih dalam tahun itu Sunan Kalijaga dan Sunan Giri mampu membuat tokoh Wayang cerita Purwo secara mandiri. Artinya, tidak dalam gulungan, bahannya sudah menggunakan kulit hewan. Dari Wayang yang dibuat dua sunan itulah, muncul sebutan sekarang: Wayang kulit atau Wayang Purwo (Sawega, 2013).

Perkembangan Wayang Purwo (kulit) lebih pesat dibandingkan Wayang dalam bentuk gulungan. Cerita Panji dalam Wayang gulungan menjadi kalah populer dibandingkan dengan cerita dalam Wayang Purwo. Mungkin ini disebabkan karena Wayang Kulit atau Wayang Purwo lebih dinamis dalam penyajiannya dibandingkan dengan Wayang gulungan (beber) yang bersifat statis. Hal tersebut karena tokohtokohnya tidak bisa digerakkan secara mandiri layaknya dalam Wayang Purwo.

Sedangkan Wayang Beber dengan cerita Jaka Kembang Kuning (WBJKK) yang terdapat di Kabupaten Pacitan merupakan pertunjukan yang mulai ditinggalkan penggemarnya. Perkembangan WBJKK ini mengalami "kemandegan" dan kurang mendapatkan sentuhan kreatifitas sehingga tidak menarik perhatian masyarakat saat ini. Sebagai salah satu bentuk seni pertunjukan, WBJKK memiliki unsur cerita yang penuh romantika, tetapi apabila kemasan pertunjukan tidak disesuaikan dengan selera masyarakat saat ini tentu pertunjukan dan cerita di dalamnya susah untuk dinikmati .
Rangkaian adegan-adegan dalam WBJKK secara tradisional disampaikan dengan bertutur menggunakan iringan musik tradisional minimalis yang terkesan monoton. Maka seiring dengan perkembangan tehnologi hiburan yang semakin maju di era modern, Wayang Beber menjadi bentuk pertunjukan yang semakin ditinggalkan (usang). Hal ini menjadi alasan untuk menciptakan lagi bentuk pementasan yang sesuai dengan selera penonton saat ini berdasar cerita dalam Wayang Beber tersebut.

Pada proses kali ini akan menggabungkan beberapa disiplin seni untuk mementaskan cerita yang terdapat dalam kesenian WBJKK. Beberapa disiplin seni memiliki cara masing-masing untuk menyampaikan misinya kepada khalayak. Apabila kekhasan masing-masing disiplin seni tersebut dirangkai dalam sebuah pementasan teater maka diharapkan mampu menghadirkan suatu penawaran bentuk yang baru sehingga mempunyai daya tarik pada penonton. Penonton tidak lagi disuguhi pementasan yang membuat mereka pasif dalam menikmatinya akan tetapi penonton diajak untuk berimajinasi lebih luas dalam menangkap cerita yang disampaikan. Proses berimajinasi pada penonton inilah yang akan membuat pementasan menjadi lebih dinamis dan tidak terasa membosankan. Penonton akan disuguhi penawaran bentuk-bentuk beberapa disiplin seni yang merangsang pemikirannya pada tiap sesi permainan. Penonton akan diajak berinteraksi dengan cara menari atau berbicara secara langsung dengan pemain.

Bentuk pementasan yang menawarkan kebebasan menafsir

Dalam masyarakat yang sudah sampai pada peradaban masa kini, tentu pertunjukan sebagai teks akan mendapatkan beberapa penafsiran yang sangat beragam tergantung pada pengalaman masing-masing 
orang untuk mempersepsikannya. Sebagian kelompok masyarakat tertentu dalam memandang sebuah karya seni akan berusaha mengaitkannya dengan pengalaman-pengalaman estetisnya selama hidupnya. Tentu saja pengalaman estetis orang perorang akan sangat berlainan karena tentu mempunyai perjalanan hidup yang berbeda-beda. Kesadaran inilah yang mendasari pemikiran masyarakat misalnya saja masyarakat seni untuk lebih berani mengekspresikan imajinasinya secara bebas dan tidak lagi terbelenggu oleh suatu tatanan pemikiran yang sudah mapan. Hal ini berbeda dengan pemahaman strukturalisme yang melihat bahwa sebuah teks sejak semula memiliki tujuan yang jelas, yaitu menyampaikan makna sebagaimana dikehendaki oleh pengarang. (Al-Fayyadl, 2011)

Dalam kesenian Wayang Beber yang telah diwariskan oleh pelaku seninya (dalang), bentuk serta pemaknaan yang terjadi berlangsung secara teratur dan berusaha untuk dipertahankan dengan maksud untuk menjaga eksistensinya seperti yang terjadi dalam prosesi ritual. Prosesi secara ritual sendiri juga terdapat di pertunjukan tradisional ini. Sebagai misal ketika sebelum musik dibunyikan sebagai penanda permainan berlangsung, sang dalang harus melakukan ritual serta menyediakan sesajen atau persembahan tertentu berupa tumpeng atau ambengan serta membakar kemenyan. Fungsi ritual di masa kini mendapatkan pemaknaan yang berbeda jika dibandingkan dengan cara pandang para pelaku seni Wayang Beber tradisional tersebut. Dalam dunia postmodern saat ini, ritual mendapatkan tempatnya yang baru, dan apa yang disebut sebagai ritual tak lain dari ritual permainan dan ritual penampilan itu sendiri. Manusia postmodern tidak berbicara mengenai eksistensi, sebab yang ada kini hanya eksistensi dalam wujud citraan (image). (Piliang, 2004).

Sedangkan gaya kesenian yang menolak eksistensi tentu akan memberikan penawaran penafsiran yang lebih terbuka. Paradigma semacam ini akan menolak pelabelan pada si pencipta sebagai satusatunya sumber intelelektual. Pendekatan utama posmodernisme terhadap gaya adalah memperlakukan gaya sebagai satu bentuk komunikasi yang dapat disebut sebagai komunikasi ironis - bentuk komunikasi, yang di dalamnya bukan makna-makna dari pesan-pesan yang dijunjung tinggi, melainkan kegairahan dalam permainan bebas tanda-tanda dan kode-kode-plesetan, humor, kritik. (Piliang, 2003). Sehingga sangat dimungkinkan apabila konteks cerita yang berlangsung dalam sebuah pementasan drama yang mengambil kisah dalamWayang Beber akan sedikit banyak bersinggungan dengan konteks sosial yang berada di luar konteks cerita Wayang Beber itu sendiri. Cerita bisa secara tiba-tiba menghadirkan persoalan sosial saat ini yang sekan-akan atau bahkan sama sekali tidak berkaitan secara langsung dengan sumber ceritanya awalnya.

Lalu bagaimana sebuah pertunjukan seni tersebut mempunyai makna tersendiri di hadapan para pemirsanya ?. Pertanyaan ini akan timbul ketika masyarakat penikmat kesenian tersebut masih pada taraf pemikiran yang bersifat tradisional. Persepsi masyarakat tradisional tentu berkaitan dengan pengalaman yang sudah pernah dialami misalnya dalam penggunaan teks bahasa (dalam hal ini pertunjukan seni WBJKK dipandang sebagai sebuah teks juga). Masyarakat (pemirsa) tentu akan membawa persepsinya masing-masing saat melihat sebuah kesenian namun apabila persepsi yang dimaksud merupakan kebebasan berimajinasi tentu akan terjadi suatukeadaan dimana teks akan mendapatkan kebebasan dalam 
pemaknaannya. Maka, seperti dikatakan Madison, ketimbang mengatakan bahwa imajinasi mengandaikan persepsi lebih baiklah mengatakan sebaliknya, yaitu : persepsi mengandaikan imajinasi. Persepsi dimungkinkan oleh imajinasi yang memainkan bahasa dengan bebas, yang karenanya dapat membayangkan kenyataan sebagai ini atau itu, bahkan dapat menganggap bahwa kenyataan "murni" adalah nama dengan konstruk interpretative yang dibuatnya itu. (Sugiharto, 1996). Dengan cara pandang semacam ini tentu akan lebih terbuka lagi tentang bagaimana menilai sebuah keindahan dalam sebuah karya (komposisi) seni. Dalam seni tradisional terdapat keteraturan-keteraturan tertentu untuk menyajikan sekaligus memaknainya sehingga sangatlah mudah bagi pemirsa untuk menangkap isi garapan yang disajikan. Hal ini berarti juga secara tidak langsung akan mengebiri imajinasi pemirsanya. Pada kenyataannya pemirsa sudah terlanjur berhadapan dengan realita sosial kekinian yang jauh berbeda dengan teks pertunjukan tradisional yang ada.

Dalam hal ini teater Indonesia harus senantiasa menggali inspirasi yang melimpah dalam khasanah teater tradisional di daerah. Dengan maksud untuk tidak meninggalkan potensi asli daerah, teater Indonesia menjadi tumpuan harapan untuk mempertegas identitas dirinya ditengahtengah pergaulan dunia yang global dengan salah satu cirinya yaitu hilangnya identitas diri. Teater tradisional memberikan keunikan dan ragam keindahan yang tak ternilai untuk senantiasa menjadi sumber penciptaan. Meski demikian harus di sadari bahwa keunikan dan karakter teater tradisional harus beradu dengan kepentingan masyarakat dan budaya asing. Teater tradisional harus mempunyai nilai tawar yang cukup untuk disandingkan dengan jenis-jenis hiburan berupa teater ataupun lainnya yang berasal dari mancanegara.
Kenyataan yang didapatkan adalah bahwa masyarakat kita lebih memilih hiburan yang bersifat instan, ringan dan murah. Penonton sudah terlalu malas untuk bersusah-susah pergi menonton pertunjukan di dalam ruang gedung pertunjukan. Sementara teater tradisional masih mempunyai kekuatan tersendiri yaitu mampu masuk keruang-ruang masyarakat secara lebih mendalam misalnya dalam acara hajatan rumah tangga. Pertunjukan harus menjemput penonton di ruang-ruang mereka agar senantiasa hidup dan dimiliki.

Sumber Ide : Pertunjukan Wayang Beber Pacitan

Pertunjukan tersebut merupakan inspirasi utama dari proses penciptaan ini perlu diamati secara seksama. Bagaimana cerita dalam tiap gulungan disampaikan oleh sang dalang, bagaimana spektakel yang digunakan untuk menarik perhatian penonton serta bagaimana reaksi penonton saat pertunjukan berlangsung. Pengamatan ini sangat penting agar penciptaan pertunjukan yang akan dilakukan mampu menjawab tantangan masyarakat saat ini.

WBJKK memiliki beberapa aspek pementasannya yang bersifat monoton yang membuat ketertarikan penonton menjadi kurang karena bersifat membosankan. Hal ini bisa disebabkan oleh dua pihak (penyaji maupun selera audiens). Penyaji tidak mempergunakan terobosan-terobosan baru karena terikat dengan kode etik tertentu pada sosialnya untuk mempertahankan bentuk pertunjukan secara tradisional, di sisi lain selera pemirsa telah mengalami perubahan yang jauh seiring dengan perkembangan kebudayaannya saat ini.

Adapun urutan penyelenggaraan Wayang Beber dapat digambarkan sebagai berikut : Dalang membakar kemenyan, kemudian membuka kotak wayang dan mengambil tiap gulungan sesuai urutan cerita. Dalang membeberkan gulungan 
pertama dan seterusnya, dengan membelakangi penonton. Dalang mulai menuturkan janturan (narasi). Setelah janturan, mulailah suluk (Lagu penggambaran) yang amat berbeda dengan suluk Wayang purwa. Kemudian suluk, dimulailah pocapan (ucapan tokohtokohnya) berdasarkan gambar Wayang yang tengah dibeberkan. begitu seterusnya sampai seluruh gulungan habis dibeberkan dan dikisahkan.

Seluruh pertunjukan diiringi dengan seperangkat gamelan Slendro yang terdiri dari rebab, kendang batangan, ketuk berlaras dua, kenong, gong besar, gong susukan, kempul. Pemain musiknya terdiri dari 4 orang yaitu sebagai penggesek rebab, petigendang, penabuh ketuk kenong, dan penabuh kempul serta gong. Sedangkan tangga nada Patet yang digunakan hanya patet nem dan patet sanga.

Setiap pagelaran Wayang Beber harus ada sesaji yang terdiri dari kembang boreh, ketan yang ditumbuk halus, tumpeng dan panggang ayam, ayam hidup, jajan pasar (kue-kue) dan pembakaran kemenyan. Untuk upacara ruwatan atau bersih desa perlu ada tambahan sesaji berupa sebuah kuali baru, kendi baru dan kain putih baru. Pertunjukan ini biasanya berlangsung sekitar satu setengah jam saja yang dapat dilakukan siang hari ataupun malam hari.

Unsur-unsur Wayang Beber yang bisa dijadikan inspirasi bagi penciptaan karya teater ini antara lain adalah cerita yang terkandung di dalamnya disajikan dengan bertutur, tembang atau lagu yang dibawakan sang dalang, gulungan cerita yang merupakan bentuk karya seni rupa, serta iringan musik berupa gamelan tradisional minimalis yang akan di aransemen dengan menggabungkan bersama peralatan modern.

Isi Cerita Wayang Beber Pacitan

Kerajaan Kediri mendapatkan
persoalan karena kehilangan puteri mahkotanya yang tiba-tiba melarikan diri dari istana saat akan dinikahkan dengan Prabu Kelana. Sekartaji sendiri sudah menjalin kasih dengan Panji Asmarabangun. Ayahanda Sekartaji lalu merasa gundah karena apabila ia menolak lamaran raja Kelana tentu peperangan yang harus dihadapinya. Maka karena ia tak ingin jatuh korban dari peperangan lalu dibukalah sayembara untuk mencari keberadaan Sekartaji. Datanglah kekasih Sekartaji sendiri, Panji Asmara Bangun, untuk mengikuti sayembara tersebut dengan cara menyamar dan mengganti namanya menjadi Jaka Kembang Kuning.

Pencarian Sekartaji oleh Jaka Kembang Kuning dimulai dengan mbarang terbang (mengamen) di kampung-kampung, tempat keramaian dan pelosok desa. Cara tersebut ternyata membuahkan hasil terbukti ketika sedang mengamen di sebuah keramaian ia bertemu dengan Sekartaji. Berita penemuan Sekartaji harus ia sembunyikan agar pihak raja Kelana yang ingin mempersuntingnya tidak mengetahui. Namun ketika akan melapor pada ayahanda Sekartaji, berita penemuan itu bocor dan sampai di telinga Raja Kelana.

Maka dengan serta merta Raja Kelana menagih janji pada Raja Kediri untuk menyerahkan Sekartaji kepadanya. Tetapi raja Kediri sudah terlanjur membuat janji kepada pemenang sayembara untuk menikahkan puterinya kepada pemenang sayembara tersebut. Akhirnya dibuatlah kesepakatan untuk melakukan perang tanding antara Jaka Kembang Kuning melawan Raja Kelana yang diwakili oleh utusan-utusannya. Perang tanding dimenangkan oleh pihak Jaka Kembang Kuning.

Raja Kelana yang tetap pada pendiriannya untuk mendapatkan Sekartaji tidak terima dengan kekalahannya lalu menantang kerajaan Kediri untuk mengadakan sebuah peperangan besar antar 
dua kerajaan. Pihak Kediri dipimpin oleh Jaka Kembang Kuning dan pihak Kelana oleh Rajanya sendiri. Kemenanganpun diperoleh pihak Kediri dengan ditandai tewasnya Raja Kelana oleh Jaka Kembang Kuning. Kerajaan Kelana yang mengalami kekalahan lalu menyerahkan seluruh harta miliknya sebagai barang rampasan dan seluruh anggota kerajaan sebagai tawanan. Kedamaian harus terus dicapai sebagai wujud kebebasan yang dicari meskipun harus penuh pengorbanan Di akhir cerita, Sekartaji akhirnya menikah dengan Jaka Kembang Kuning dengan disaksikan oleh Dewi Kilisuci yaitu kakak sang Raja Kediri.

Membaca Kembali (reinterpretasi) Tema Cerita Jaka Kembang Kuning

Cerita Jaka Kembang Kuning dalam Wayang Beber Pacitan ini bertemakan "perjuangan meraih cinta sejati dengan segala pengorbanan". Sekartaji harus rela meninggalkan segala atribut kebangsawanannya demi meraih cintanya. Ia tidak mau begitu saja menyerahkan dirinya pada orang yang bukan menjadi pilihan hatinya. Keberadaan dirinya sebagai manusia yang rindu akan kebebasan mendorongnya untuk lepas dari persoalan kenegaraan yang membelenggunya. Ia tak mau membebani keluarganya dengan menolak secara terus terang tekanan asing yang berupa lamaran kepadanya. Dengan cara melarikan diri maka keluarganya tidak akan dianggap dengan sengaja menolak tekanan asing tersebut.

Di pihak Jaka Kembang Kuning sendiri mempunyai sudut pandang bahwa keinginan apapun harus dicapai dengan pengorbanan setinggi-tingginya. Ia tidak akan bisa mendapatkan cinta sejati tanpa melakukan apapun dan rela untuk berkorban. Maka meski apapun yang terjadi ia harus berhadapan dengan kekuatan asing yang mungkin tidak seimbang dengan kekuatannya sendiri. Ia harus berusaha meyakinkan segala pihak untuk memberinya kepercayaan memperjuangkan nasibnya. Dengan keberanian siap menanggung segala resiko dan konskwensi yang dihadapi.

Secara garis besar cerita ini apabila dikaitkan dengan peristiwa kekinian akan terdapat beberapa hal yang mungkin terjadi. Sebagai misal adalah keinginan yang hakiki seseorang terhadap kebebasan mempunyai konskwensi tersendiri apabila harus berhadapan dengan keinginan pihak lain yang menginkan kebebasan pula. Raja Kelana merupakan sosok yang juga menginginkan kebebasan dalam memenuhi hasratnya mendapatkan perempuan pujaannya. Namun keinginan tersebut harus bersinggungan dengan kepentingan pihak lain yang mutlak membutuhkan proses negosiasi. Kadang proses negosiasi mengalami kebuntuan dan rasa frustasi sehingga memilih untuk melakukan intervensi pada keinginan orang lain karena kekurang mampuan bernegosiasi terhadap diri sendiri. Dalam hal ini konflik terbuka akan terjadi sebagii proses seleksi alam dimana yang kuatlah yang bisa bertahan.

Perwujudan

Dalam teori Montage (montase), Eugenio Barba (1991) mengatakan bahwa montase adalah kata yang saat ini menggantikan istilah komposisi dulunya. Untuk mengatur (menempatkan) juga berarti menyusun, untuk menata keseluruhan, tindakan merangkai keseluruhan: untuk mencipta permainan. Komposisi merupakan perpaduan bahan baru dan bagian yang diambil di luar konteks aslinya.

Maka pada pertunjukan kali ini menghadirkan peristiwa-peristiwa baru yang ada dalam masyarakat saat ini yang sebenarnya tidak dalam konteks cerita Panji namun masih mempunyai hubungan tertentu, misalnya permasalahan sosial kemanusiaan yang masih relevan. Secara konkret, sang dalang atau pemain 
menggunakan istilah atau kata-kata yang populer pada masa kini yang hal tersebut tidak ditemui pada zaman cerita Jaka Kembang Kuning yang asli, tetapi penggunaan istilah tersebut tetap masih dalam maksud menceritakan alur lakon Jaka Kembang Kuning.

Selanjutnya Barba

menyampaikan bahwa sebuah pertunjukan lahir dari hubungan spesifik dan dramatis antar elemen yang detail, yang dianggap terpisah, baik yang tidak dramatis maupun yang tampaknya tidak memiliki kesamaan apa pun. Konsep montase bahkan tidak menyiratkan komposisi kata, gambar, atau beberapa hubungan. Tetapi itu menyiratkan gabungan ritme, meski tidak bermaksud untuk menggantikan atau untuk mengurangi gerakan. Meskipun dengan cara menggabungkan beberapa ritme, tetapi salah satunya bertujuan sebagai acuan gerak, pada ketegangan, pada proses dialektika alam atau pikiran. Lebih jelasnya, pada pemikiran yang menembus materi.

Jadi meskipun dalam pertunjukan yang diciptakan ini terdapat percampuran dari berbagai disiplin seni, akan tetapi terdapat sebuah benang merah yang menjadikan semua unsure sebagai satu kesatuan permainan. Sebagai pengikat cerita, tokoh tokoh sentral yang ada dalam cerita Jaka Kembang Kuning ini digambarkan dengan sosok pemain yang mempunyai keterampilan menyanyi atau menari sebagai alat ucapnya.

Maka jika mengacu pada bentuk opera tentu mempunyai kedekatan meski harus dilihat juga batasan-batasannya. Di dalam pertunjukan opera juga menggunakan aktifitas menyanyi dan menari. Beberapa orang menyukai adegan-adegan megah, pertunjukan nyanyian, lirik yang mengulang kata-kata terus menerus. Dr. Samuel Johnson dalam kamus besarnya mendefinisikan: "Opera-sebuah hiburan yang eksotik dan irasional"; dan penulis
Perancis Beaumarchais mengatakan bahwa opera harus dinyanyikan karena katakatanya yang begitu aneh dan tidak ada seorangpun yang mampu mengucapkannya. (Kernodle, 1967).

Bahasa Jawa kuno pada Wayang Beber ini merupakan bahasa yang jarang atau bahkan tidak lagi dipakai dalam kehidupan sehari-hari untuk percakapan. Untuk memahami hal tersebut penonton cukup menyaksikan gerakan tubuh pemain, ekspresi serta mendengarkan suasana lagu yang dibawakannya. Hal tersebut merupakan isyarat-isyarat untuk mengemukakan teks agar dapat dipahami.

Bila kita mengamati bagaimana seseorang pendengar menggunakan berbagai cara isyarat ekspresi dalam keseharian untuk merekognisi emosi, sangat dimungkinkan untuk menggunakan kombinasi dari kinerja suara yang telah disintesiskan. Seperti telah dikemukakan beberapa peneliti, memang sulit untuk mengetahui variasi kinerja mana yang penting sehubungan dengan ekspresi. Pertama-tama telah diketahui bahwa variasi tersebut adalah sistematis, sebagai lawan dari variasi acak atau noise (ribut). Reliabilitas kinerja dapat diukur misalnya dengan memberikan tugas pada penyaji untuk mengulangi interpretasi yang sama dari sebuah lagu beberapa kali. Selanjutnya, variasi variasi juga dapat menjadi bagian dari intensitas penyaji. Ini dapat diuji melalui manipulasi pada intensitas ekspresi. Akibatnya, dapat dipastikan bahwa semua variasi akan terasa oleh pendengar dan akan menjadi efektif bila berhubungan dengan ekspresi. Dengan kata lain, harus dapat diketahui variasi-variasi mana yang diperlukan oleh pendengar dalam mengatribusikannya. Hal ini dapat membuat pendengar bereksperimen dengan menggunakan variasi sistematis dalam mendengarkan berbagai variasi suara sebagai stimulus. 
Suluk atau nyanyian dalam Wayang Beber untuk menggambarkan situasi cerita oleh sang Dalang digantikan oleh penyanyipenyanyi dengan lagu yang diciptakan dengan mengambil inspirasi dari suluk tersebut. Kehadiran paduan suara (acapella) secara minimalis membantu pertunjukan menjadi lebih dinamis. Selain adanya paduan suara secara acapella, penyanyi juga bermain musik sambil menari dan menyanyi, menceritakan adegan atau memainkan dialog dalam bentuk lagu seperti halnya operet. Operet umumnya memiliki cerita romantis yang diatur dalam beberapa peristiwa secara terpisah. Suasana ketidaknyataan dan meyakinkan membuat Operet berada jauh dari peristiwa keseharian. Tapi salah satu ciri menarik yang dimiliki, penggunaan melodi tinggi dan plot untuk menyampaikan sebuah cerita secara utuh, namun fantastis. Operet berisikan solo, duet, trio serta mencampur beberapa paduan suara. (Wilson, 2004)

Sebuah proses pembentukan tidak bisa terlepas dari peran sutradara yang terlebih dahulu melihat sejauh mana konsep yang diusung dalam proses dan bagaimana cara mewujudkannya. Penciptaan teater Jaka Kembang Kuning ini melibatkan penonton secara aktif dalam permainannya tetapi masih menggunakan cerita aslinya yang berusaha ditampilkan dengan simbol-simbol tertentu sehingga menggugah impuls atau hasrat penonton untuk ikut bermain dan berfikir di dalamnya. Bentuk teater ini merupakan bentuk Teater Terlibat atau The Immediate Theatre, yaitu merupakan teater yang menggabungkan teater Kasar (Rough Theater) dan Teater Kudus (Holy Theater). Penonton diajak untuk berinteraksi bersamasama dengan pemain. Bentuk teater seperti ini berusaha untuk manghilangkan batas kehidupan keseharian dengan kehidupan di atas panggung. Proses yang bisa dilakukan sutradara dalam membentuk tokoh tokohnya meliputi repetisi, representasi, asistensi, istilah untuk menyatakan "bekerja dengan baik", dalam istilah Inggris. Tapi kita biasanya berbicara tentang latihan yaitu: "pengulangan" dalam bahasa Perancis, dan maksud kata-kata tersebut mengarah dari proses secara mekanik. Minggu demi minggu, hari demi hari, jam demi jam, praktek menjadikan sempurna. Ini adalah sebuah kerja keras, sebuah kesibukan, disiplin, yang merupakan tindakan membosankan yang mengarah ke hasil yang baik.

Sedangkan Representasi adalah keadaan ketika sesuatu dari masa diwakili, pada saat keadaan masa lalu ditampilkan kembali sehingga sesuatu yang dulu menjadi kekinian. Maka representasi di sini bukanlah tiruan atau deskripsi peristiwa masa lalu, representasi menyangkal waktu. sesuatu yang menghapuskan perbedaan antara kemarin dan hari ini.

Kemudian asistensi (mendampingi) merupakan kata yang sederhana: itu adalah kuncinya. Dalam latihan, elemen yang penting adalah bantuan dari sang sutradara, yang hadir untuk mendampingi dengan mengamati. Ketika aktor berjalan di depan penonton, perubahan tidak terjadi dengan keajaiban. Para penonton mungkin hanya tahu pertunjukannya, mengharapkan aktor untuk menyelesaikan seluruh pertunjukan dan sebelum penonton menyadarinya, aktor telah memahami bahwa semua yang dapat dia pertunjukkan adalah hasil pengulangan latihan.

Penyutradaraan Teater Jaka Kembang Kuning

Menurut George R. Kernoddle (1967) ruang lingkup atau wilayah kerja sutradara terdiri dari tiga tahap. Perencanaan, pelatihan dan pertunjukan. Bagi sutradara pilihan materi yang akan digunakan untuk menuangkan idenya berupa akting, ruang, waktu, garis, warna, cahaya. Sedangkan tehnik yang digunakan adalah 
komposisi, gambar/sketsa,pergerakan, dramatisasi pantomimik, irama. Bagi aktor pilihan materi yang dapat mereka pergunakan adalah tubuh, suara, pikiran, perasaan. Tehnik yang bisa dipergunakan antara lain, membaca sinopsis adegan, pergerakan, dramatisasi pantomimik, irama, gesture, menyanyi. Bagi perancang artistik pilihan materi dapat berupa garis, warna, bentuk. Sedangkan tehnik yang akan dipakai adalah mendalami atmosfer pertunjukan, teks dan konteks serta komposisi.

Naskah diterjemahkan dari naskah drama (dari gambar dan tulisan) menjadi naskah utuh, divisualisasikan dalam ruang, waktu, dan warna pemanggungan oleh sutradara. Secara singkat, gambar wayang beber diubah menjadi urutan peristiwa (sinopsis) adegan per adegan agar mempermudah dalam membentuknya menjadi permainan. Cerita yang akan dimainkan terdiri dari enam gulungan. Masing-masing gulungan memiliki 4-5 adegan. Melalui adegan-adegan yang berlangsung tersebut sutradara meringkasnya menjadi beberapa peristiwa pertunjukan berupa monolog, dialog, tembang, gerak teatrikal maupun permainan musik tertentu. Gambar yang diciptakan berupa kolase atau bertumpuk-tumpuk seakan tidak memiliki keterkaitan peristiwa.

1. Plot pertunjukan Teater Jaka Kembang Kuning

Pementasan teater Jaka Kembang Kuning sebenarnya telah memiliki plot sendiri saat dipentaskan dalam pertunjukan Wayang Beber tradisional. Seperti halnya struktur dramatik yang dikemukakan aristoles yang mempunyai suatu kesatuan dari tiap bagian ceritanya, yang apabila salah satu unsurnya dirusak maka akan merusak seluruh bangunan cerita yang disampaikan. Bagian yang dimaksud Aristoteles tersebut secara berurutan meliputi eksposisi komplikasi kilmaks resolusi konklusi. Namun demikian dalam proses kali ini plot akan berkembang menjadi lebih terbuka. Rangkaian cerita yang terdapat pada pertunjukan Jaka Kembang Kuning kali ini menggunakan plot yang fleksibel artinya keterakitan antara peristiwa satu dengan peristiwa berikutnya tidak berlangsung ketat secara hubungan sebab-akibat sebagaimana dalam struktur dramatik Aristoteles tersebut.

2. Penokohan

Tokoh tokoh yang ada dalam WBJKK mempunyai karakter yang akan digambarkan secara bervariasi. Beberapa cara untuk menggambar tokoh antara lain dengan Monolog karena bentuk penceritaan secara monolog lebih memberikan imajinasi secara lebih terbuka bagi penonton jika dibandingkan dengan mewujudkannya secara visual misalnya tentang set dan artistiknya. Pada bentuk monolog penonton akan dihadapkan pada teks-teks bersifat naratif mengenai peristiwa cerita.

Dialog yang terjadi dalam permainan akan di bedakan menjadi dua arah yaitu antar pemain itu sendiri maupun pemain dengan penonton. Dialog yang dilakukan antar pemain melibatkan pemain itu sendiri yang sedang memainkan tokoh-tokoh dalam cerita sehingga membatasi komunikasi dengan penonton secara langsung. Hal ini bermaksud agar memberi ruang imajinasi bagi penonton saat menyaksikan permainan secara pasif. Pada saat dialog terjadi secara terbuka antara pemain dengan penonton maka efek permainan yang terjadi bersifat lebih akrab. Penonton tidak lagi dibuai oleh imajinasinya sendiri tetapi langsung dilibatkan dalam permainan. Pemain berbicara secara langsung ataupun bertanya jawab dengan penonton sesuai konteks permainan yang berlangsung tetapi untuk mengarah pada pembicaraan di dalam konteks keseharian akan sangat mungkin terjadi.

Dalam adegan tertentu kegiatan nembang (menyanyi) berbahasa jawa ini 
menguntungkan sekali untuk menciptakan ilustrasi tertentu pada teks yang disampaikan. Dalam bentuk tembang teks sekaligus menjadi ilustrasi terhadap dirinya sendiri pada saat disampaikan. Bentuk tembang yang digunakan bisa macapat secara bersamaan (grup) atau sendiri (solo).

Adakalanya sebuah peristiwa sangat gamblang dan kurang menarik apabila disampaikan dengan bunyi. Beberapa gerakan teatrikal pada adegan tertentu menggunakan property berupa topeng. Topeng mempunyai daya tarik tersendiri serta mempunyai keuntungan dalam memberi gambaran pergantian karakter tokoh secara cepat tidak seperti halnya dengan make-up wajah. Topeng sewaktuwaktu bisa dilepas dan dikenakan kembali sesuai situasi yang diinginkan. Topeng dimainkan secara teatrikal dalam bentuk permainan tari dengan iringan tertentu secara minimalis.

Selain itu penggunaan permainan musik mempunyai tafsir yang lebih luas lagi karena sifatnya yang abstrak. Pada beberapa kalangan, sebuah komposisi musik bernilai berbeda dengan kalangan lainnya. Misalnya penggunaan tangga nada yang mayor atau minor diatonik memberikan kesan berbeda. Akan tetapi komposisi musik yang dihadirkan disesuaikan dengan selera musik penonton secara umum, misalnya musik rock memberikan kesan cadas, semangat, pertarungan dinamis. Sedangkan musik mellow akan memberikan kesan lemah, sedih, kalah, pasrah.

Beberapa adegan tertentu pada cerita ini masih diceritakan dengan cara memainkan wayang di adegan tertentu. Namun wayang tidak ibeberkan dengan kertas gulungan akan tetapi menggunakan proyektor agar terlihat lebih jelas dari jarak pandang yang agak jauh. Hal ini bertujuan agar pertunjukan ini masih memiliki kaitan secara langsung dengan bentuk penceritaan yang terdahulu agar identitas Wayang Beber yang melekat pada ceritanya masih melekat.

Pembentukan

Naskah diubah bentuknya menjadi tubuh dan suara aktor, serta perancang artistik merancang naskah menjadi elemen pertunjukan.Untuk itu latihan secara terpisah bisa dilakukan pada awal penciptaan. Kemudian pada tahap berlatih secara Run Through akan dilaksanakan bersamaan seluruh pemain. Pada tahap latihan secara terpisah (masing-masing disiplin seni) eksplorasi bentuk serta komposisi permainan dicari bersama-sama sutradara. Eksplorasi yang dilakukan selain di dalam ruangan (studio) juga dilakukan di luar ruangan, misalnya di pantai, hutan atau lapangan. Sutradara memilih dan menyeleksi beberapa unsur permainan yang ditawarkan oleh masing-masing pendukung pementasan.

Pada eksplorasi suara pemain dengan latar belakang penyanyi melakukan pendekatan-pendekatan nada dari susunan nada pentatonis maupun diatonis. Pemain berlatih menyuarakan tangga nada tersebut serta memainkan beberapa lagu dengan dua tangga nada tersebut. Setelah itu pemain mencoba untuk dibebaskan dalam memilih nada sendiri untuk mengekspresikan teks yang harus disampaikan sehingga berbentuk menjadi sebuah nyanyian tertentu. Begitu juga halnya dengan pemain musik.

Pada pemain-pemain yang menggunakan gerakan tubuh sebagai alat ekspresi maka eksplorasi bisa dilakukan dengan cara meniru gerakan manusia keseharian dan gerakan yang terdapat dalam pose tokoh-tokoh di lukisan Wayang Beber. Gerakan gerakan tersebut kemudian dipilih dan dirangkai menjadi sebuah alur yang membicarakan peristiwa dalam adegan yang dipilih.

Untuk mentransformasi cerita dari adegan yang bersifat tulisan menjadi permainan panggung maka diperlukan 
proses eksplorasi tertentu. Pada tahap latihan secara terpisah (masing-masing disiplin seni) eksplorasi bentuk serta komposisi permainan akan dicari bersama-sama sutradara. Eksplorasi yang dilakukan selain di dalam ruangan (studio) juga dilakukan di luar ruangan, misalnya di pantai, hutan atau lapangan. Sutradara akan memilih dan menyeleksi berapa unsur artistik yang ditawarkan oleh masing-masing pendukung pementasan.

Proses latihan yang menggunakan tempat dalam ruangan lebih menekankan pada proses pengadegan dan run through sedangkan latihan yang bersifat eksplorasi banyak dilakukan di luar ruangan. Hal ini mempunyai tujuan masing masing. Pada tahap latihan di dalam ruangan, konsentrasi dalam pengadegan akan lebih menguntungkan karena pemain akan lebih focus terhadap adegan yang di ciptakan. Sedangkan proses luar ruangan lebih menguntungkan dari sisi pencarian gerak dan imajinasi pemain untuk menggali potensinya secara lebih bebas.

Pada eksplorasi suara pemain dengan latar belakang penyanyi melakukan pendekatan-pendekatan nada dari susunan nada pentatonis maupun diatonis. Pemain berlatih menyuarakan tangga nada tersebut serta memainkan beberapa lagu dengan dua tangga nada tersebut. Setelah itu pemain mencoba untuk dibebaskan dalam memilih nada sendiri untuk mengekspresikan teks yang harus disampaikan sehingga berbentuk menjadi sebuah nyanyian tertentu. Begitu juga halnya dengan pemain musik.

Setelah beberapa gerakan dan pola ucap serta tehnik lain diperolah dalam eksplorasi maka tahap selanjutnya adalah membaca adegan yang telah di susun sebelumnya. Melalui uraian pada tiap adegan tersebut kemudian sutradara menterjemahkannya lagi bersama para pendukung pementasan mengenai cara yang dipilih untuk mengekspresikannya berdasar dari hasil eksplorasi yang telah dilakukan.

Masing-masing pendukung dari beberapa disiplin seni akan memilih cara pengungkapan ekspresi adegan bersama sutradara. Apabila dalam tahap mewujudkan adegan masih belum memuaskan maka dilakukan proses eksplorasi lagi sampai menemukan pola permainan yang dinilai tepat sesuai dengan adegan serta suasana yang di harapkan.

Eksplorasi luar dan dalam ruangan dan improvisasi

Proses yang dilakukan di luar ruangan membutuhkan kesiapan mental dan fisik pesertanya. Peserta dihadapkan pada lingkungan yang lebih bebas dari keterbatasan sosial maupun geografis selayaknya di ruang tertutup. Peserta mencari kecenderungan yang biasa dilakukan dalam bergerak untuk kemudian dikembangkan ke luar dari batas kebiasaan sehari-hari. Pada saat-saat tertentu pemain benar-benar melawan kebiasaan yang membuat gerakan pada tubuhnya menjadi monoton dan kurang lentur. Peserta harus merespon sensasi yang diperoleh dari alam secara langsung misalnya rasa dingin, panas, bau, lalu menjadikannya sebuah gerakan tertentu secara bebas.

Situasi di dalam ruangan tentu berbeda sekali dengan luar ruangan. Ruang memberikan atmosfer sesuai dengan karakter bentuk serta lingkungan yang mempengaruhinya. Keterbatasanketerbatasan yang dimiliki oleh dinding, lantai serta atap dan perabot di dalamnya harus mampu ditangkap oleh peserta latihan sebagai daya rangsang terhadap alat tubuhnya. Peserta berusaha mengakrabi unsur-unsur ruangan menjadi bagian dari dirinya. Kemampuan mengukur diri dan lingkungannya sangat diperlukan sehingga kesadaran keberadaan tubuh peserta dilatih sebagai tahap adaptasi terhadap lingkungan 
yang baru dan lebih dinamis nantinya (dalam pertunjukan). Eksplorasi dalam ruangan bertujuan untuk mengasah kemampuan berimprovisasi ketika peserta harus berhadapan dengan keterbatasan ruang.

Ketika seorang pemain harus berhadapan dengan situasi yang tidak pernah terduga sebelumnya maka ia harus menghadapinya dengan pengambilan sikap secara cepat dan tanpa perencanaan terlebih dahulu. Sikap yang muncul ketika peserta secara spontan dan tanpa perencanaan seringkali berwujud sikap yang pernah terpola dalam dirinya. Dari hasil eksplorasi dalam dan luar ruangan, pemain diajak untuk mencoba mewujudkan komposisikomposisi tertentu berdasar rangsang dari situasi yang terdapat dalam adegan secara tiba-tiba. Pemain harus mampu menangkap lontaran ekspresi dan sikap dari sutradara maupun pemain lain secara cepat tanpa harus merencanakannya terlebih dahulu.

\section{Penutup}

Cerita yang terdapat dalam Jaka Kembang Kuning berkisar tentang kisah asmara dan kepahlawanan. Di dalamnya berisi cerita tentang tokoh yang berusaha mendapatakan kebebasan dalam menentukan pendamping hidupnya. Sekartaji sebagai tokoh yang menolak untuk dikawinkan dengan Raja penjajah bisa dipersonifikasikan sebagai pemberontakan sosok anak muda yang tidak mau membiarkan kebebasannya dirampas. Orang lain kadang memaksakan kehendaknya. Namun ternyata pilihan kebahagiaan dalam hidup masing-masing orang tidak bisa ditentukan oleh orang lain meskipun orang terdekatnya. Di sisi lain juga diketengahkan kisah kepahlawanan seorang pemuda yang rela mempertaruhkan jiwanya demi mendapatkan cintanya. Cinta yang dimaksud di sini adalah perlambang bagi kebebasan yang senantiasa di kejar oleh setiap manusia.
Cinta yang tidak didasari dengan paksaan merupakan simbol dari kebebasan yang ingin diraihnya.

Kemudian bagaimana cara memberikan tafsir secara bebas agar sesuai dengan semangat kekinian adalah dengan cara menghadirkan teks-teks kekinian pula. Sebagai misal di dalam sebuah adegan akan muncul istila-istilah yang dipergunakan dalam masyarakat saat ini terutama masyarakat jawa tempat cerita Jaka Kembang Kuning ini berasal. Bagi penonton istilah-istilah yang akrab dalam keseharian mereka diharapkan mampu mewakili realita mereka secara langsung mupun tidak langsung.

Pada setiap unsur pertunjukan yang disajikan akan memberikan sensasi terhadap indera pandang dan dengar penonton. Perubahan pola ungkap dari dialog, monolog, menyanyi, permainan musik dan permainan wayang akan membentuk dinamika perunjukan lebih intens. Penonton tidak akan terjebak dalam pertunjukan yang monoton dan bahkan penonton diberikan ruang untuk berkreatifitas yaitu dengan cara bersentuhan langsung dalam permainan. Keterlibatan penonton secara aktif terhadap jalannya pertunjukan inilah yang akan menjadi ciri khas pertunjukan ini.

Bentuk kesenian tertentu akan memberikan konskwensi tersendiri terhadap respon pemirsa. Apabila kesenian Wayang Beber ini mampu dikembangkan dengan lebih maju dan memperhatikan selera pemirsanya maka akan memberi nilai tambah bagi warga pendukung kesenian ini. Kesenian wayang beber akan menjadi lebih akrab dan mewakili kepribadian masyarakatnya yaitu masyarakat desa kedompol, kecamatan Donorojo Kabupaten Pacitan Jawa Timur. Pendapatan masyarakat dari sisi ekonomi serta sosial tentunya akan lebih meningkat karena perubahan tersebut.

Kesenian merupakan cara untuk memandang sebuah peristiwa tertentu. 
Melalui bentuk kesenian semacam ini cara memandang persoalan hidup diharapkan akan lebih luas dan terbuka. Kesenian menjadi sarana untuk memperluas cakrawala berpikir pemirsa sehingga tidak terjebak pada penyempitan makna di saat menghadapi sebuah fenomena sosial. Cara menyajikan sebuah cerita akan berpengaruh pada cara berpikir para pemirsanya.

\section{Daftar Pustaka}

Al-Fayyadl, M. (2005). Derrida. Yogyakarta: LKis.

Barba, E., \& Savarese, N. (1991). A Dictionary Of Theatre Anthropology, The Secret Art Of The Performer. London: Routledge

Haryanto, S. (1988). Pratiwimba Adhiluhung, Sejarah dan Perkembangan Wayang. Jakarta: Djambatan.

Kernodle, G. R. (1967) Invitation To The Theatre. Boston: Hartcourt, Brace \& World. Inc.

Piliang, Y. A. (2003). Hipersemiotika, Tafsir Cultural Studies Atas Matinya Makna. Yogyakarta: Jalasutra.

Piliang, Y. A. (2004). Posrealitas, Realitas Kebudayaan dalam Era Postmetafisika. Yogyakarta: Jalasutra.

Sawega, A. M. (2013), Wayang Beber, Antara Inspirasi dan Transformasi. Solo: Bentara Budaya Balai Soedjatmoko.

Sugiharto, I. B. (1996). Postmodernisme, Tantangan Bagi Filsafat. Yogyakarta: Kanisius.

Wilson, E. (2004), The Theater Experience. New York: McGraw-Hill. 